\title{
Sprawozdanie z Krakowskiej Konferencji Onkologicznej
}

W dniach 18-19 września 2014 roku w Krakowie odbyła kolejna, III Krakowska Konferencja Onkologiczna, zorganizowana przez Krakowski Komitet Zwalczania Raka (KKZR). Tematem przewodnim Konferencji były postępy w diagnostyce i leczeniu nowotworów złośliwych. Krakowski Komitet Zwalczania Raka został założony w 2010 roku i ma na celu kreowanie wszelkich działań związanych z profilaktyką, diagnostyką i leczeniem chorych na nowotwory oraz wspieranie rozwoju naukowego. Konferencja odbywa się co rok; bieżąca - była już trzecim wielodyscyplinarnym spotkaniem onkologicznym w Krakowie. O jej rosnącej popularności świadczy duża liczba uczestników: w tym roku było to około 200 osób. Obrady odbyły się w Hotelu Europejskim, położonym w ścisłym centrum Krakowa.

Uczestników Konferencji przywitał i zarazem dokonał uroczystego otwarcia Zarząd Krakowskiego Komitetu Zwalczania Raka: prof. Andrzej Stelmach, dr Zbigniew Darasz, dr Ida Cedrych oraz Dyrektor Krakowskiego Oddziału Centrum Onkologii prof. Jerzy Jakubowicz, a także Prezes Okręgowej Rady Lekarskiej w Krakowie - prof. Andrzej Matyja.

W pierwszym dniu Konferencji prof. Edward Towpik zaprezentował wykład dedykowany Prof. Janowi Skołyszewskiemu, zatytułowany "Dar Narodowy dla Marii Skłodowskiej-Curie: w 90 rocznicę powstania idei". Wykład ten był szczególny - Wykładowca posiada pasję odszukiwania nieznanych faktów historycznych i przedstawiania ich w niezwykle interesujący sposób. Po tym wykładzie uroczyście podziękowano prof. Janowi Skołyszewskiemu za wieloletnią pracę dla polskiej onkologii, wybitne osiągnięcia w zakresie radioterapii onkologicznej, za najwyższy szacunek dla zdrowia i życia ludzkiego oraz za wieloletnie poświęcenie i wysiłek na rzecz Krakowskiego Oddziału Centrum Onkologii, którym przez wiele lat kierował.

Program Konferencji był bardzo bogaty, obejmował szeroki zakres tematyczny, w tym zagadnienia z zakresu m.in.: chirurgii onkologicznej, urologii, ginekologii, radioterapii oraz onkologii klinicznej. Sesje podzielono pod względem tematycznym — narządowym. Sesja inauguracyjna dotyczyła postępów i rozwoju onkologii w Polsce; w jej trakcie swoje doświadczenia prezentowali prof. Marek Sosnowski, dr Istvan Petak, prof. Piotr Rutkowski, prof. Maciej Krzakowski oraz prof. Jacek Fijuth. W sesji kardio-onkologicznej poruszono temat toksyczności kardiologicznej i prewencji niewydolności serca indukowanej leczeniem onkologicznym.
Prezentacje przedstawili dr Aleksandra Grela-Wojewoda, doc. Andrzej Wygoda, dr Sebastian Szmidt, prof. Roman Pfitzner i dr Tomasz Drewniak. W kolejnej sesji, obejmującej problematykę nowotworów układu moczowo-płciowego, prelegenci (prof. Piotr Chłosta, prof. Tomasz Demkow, dr hab. Jakub Dobruch, dr Ewelina Szliszka) zaprezentowali własne doświadczenia z zakresu leczenia pacjentów z rakiem stercza oraz pęcherza moczowego. W sesji zatytułowanej „Postępy w onkologii" temat nowych technologii w radioterapii i leczeniu raka stercza oraz raka piersi zaprezentowali kolejno: prof. Beata Sas-Korczyńska, dr Janusz Jaszczyński, dr Tomasz Dąbrowski, dr hab. Beata Biesaga, dr Marek Jasiówka, dr Marek Ziobro. Także na specjalne zaproszenie KKZR wykład przedstawił również prof. Wojciech Zegarski. Dotyczył on nowoczesnego leczenia raka jelita grubego w ramach specjalistycznych jednostek (Colorectal Unit). Wystąpieniom ustnym towarzyszyły prezentacje multimedialne i filmowe przedstawiające techniki operacyjne stosowane w chirurgii w różnych ośrodkach. Każdemu wystąpieniu towarzyszyła dyskusja, umożliwiająca zadawanie nurtujących uczestników pytań. Współczesna onkologia znajduje się w bardzo ciekawym okresie, ponieważ wieloletnie badania w laboratoriach nad lekami celowanymi znajdują zastosowanie w coraz szerszym zakresie u chorych na nowotwory złośliwe.

Krakowska Konferencja Onkologiczna organizowana przez KKZR stanowi forum dla onkologów z Polski południowej, a także z innych części kraju. Tematyka Konferencji stworzyła możliwość wymiany doświadczeń z lekarzami z innych ośrodków orazzapoznania się z nowymi trendami w interdyscyplinarnym leczeniu pacjentów onkologicznych. Mamy nadzieję, że przyszłoroczna, IV Krakowska Konferencja Onkologiczna zgromadzi jeszcze więcej uczestników i przyniesienie nowe doniesienia z obszaru diagnostyki i leczenia nowotworów złośliwych.

\section{Dr n. med. Jerzy Władysław Mituś}

Centrum Onkologii — Instytut im. Marii Skłodowskiej-Curie, Oddział w Krakowie

Katedra Anatomii, Uniwersytet Jagielloński,

Collegium Medicum w Krakowie

e-mail:Jerzy.Mitus@gmail.com

Dr n. med. Zbigniew Darasz

Centrum Onkologii — Instytut im. Marii Skłodowskiej-Curie, Oddział w Krakowie

Prezes Krakowskiego Komitetu Zwalczania Raka

e-mail:zbigniew.darasz@gmail.com 